\title{
Behavioural methods to assess the effects of pesticides on honey bees
}

\author{
Minh-Hà Pham-Delègue ${ }^{\mathrm{a} *}$, Axel DeCourtye $^{\mathrm{a}}$, \\ Laure KAISER ${ }^{\mathrm{a}}$, James DEVILLERS ${ }^{\mathrm{b}}$ \\ ${ }^{\text {a }}$ Laboratoire de Neurobiologie Comparée des Invertébrés, INRA, BP 23, 91440 Bures-sur-Yvette, France \\ ${ }^{\mathrm{b}}$ CTIS, 3 chemin de la Gravière, 69140 Rillieux La Pape, France
}

(Received 2 February 2001; revised 11 January 2002; accepted 24 April 2002)

\begin{abstract}
We reported on the use of experimental procedures dealing with these behavioural skills in the assessment of pesticide effects. The relevance of the following methods are discussed: (1) use of automatic activity counters set at the hive entrance to establish the balance between outgoing and incoming worker bees; (2) observation of the homing flights of bees; (3) the analysis of the information encoded in the dances of returning foragers; and (4) recording of the conditioned proboscis extension response on restrained bees to evaluate individual learning performances involved in foraging behaviour. These behavioural assays could be developed for sublethal toxicity assessment. However, careful validation of the tests is needed before being used in a routine evaluation procedure. At a minimum, they are valuable tools to understand the mechanisms underlying insecticide toxicity.
\end{abstract}

\section{Apis mellifera / ecotoxicology / risk assessment / pesticide / behaviour}

\section{INTRODUCTION}

Honey bees, Apis mellifera L., are ecologically and economically important insects. Honey bees ensure the pollination of many wild flowers, and thus contributing to plant biodiversity. The economic value of honey bees results not only from the hive products (honey, royal jelly, wax) but also from their pollinating activity on crop plants (Williams, 1994). Under temperate climatic conditions, pollination activity takes place from early spring (March-April) to mid-autumn (beginning of October). Therefore honey bees may be exposed to repeated applications of chemical pesticides.

When assessing potential risks of pesticides on honey bees, one has to consider the specific- ity of bee biology, in particular their social organisation. Social behavior relies on task distribution; the performance of different duties by individual bees depending on their age, genetic background, and environmental conditions (Calderone and Page, 1992). Most often, younger bees are involved in hive duties (nursing, cleaning, cell building) then some become guards, and older bees start to forage (Seeley, 1982). Not only foragers visiting crops are exposed to pesticides, hive bees and larvae feeding on pollen and nectar stored in the combs are also exposed. This means that different lifestages of honey bees (larvae and adults of various ages or involved in different duties) can be exposed. Also, the concentration and duration of the exposure can vary: the quantity of chemicals, the persistence of residues, and the

* Correspondence and reprints

E-mail: pham@jouy.inra.fr 
frequency of spraying on the crop are not the only information to take into account, since the product can be accumulated over long periods in the hive, and subjected to degradation/concentration processes. Therefore, it is especially important to estimate the actual risk, which results from the combination of the toxicity of the chemical and the exposure of bees to the product. In addition, both lethal and sublethal effects should be considered. While lethal effects are rather easy to determine and can lead to discarding a product, more subtle effects at various levels of bees physiology or behaviour are less obvious to detect, but may also affect honey bee populations. The honey bee risk assessment scheme in Europe tentatively takes into account these different aspects (EPPO, 1993).

When the standard procedures are insufficient to determine the effect of a product, the official decision scheme recommends the use of other studies that could provide additional information. However, there is no reference to specific studies. In the context of a growing concern about environmental effects of pollutants, more standardised methods to evaluate sublethal effects of pesticides, especially on bee behaviour, may be needed.

\section{METHODS TO ASSESS BEHAVIOURAL EFFECTS OF PESTICIDES}

A recent review of research dealing with ecotoxicological effects of xenobiotic compounds on the honey bee transmitted to the French Agriculture Ministry in 2000 in the frame of an European programme to support French beekeeping covered the period from 1949 to 1999, and gathered more than 500 references. These studies can be classified according to the type of products considered, which includes not only different kind of pollutants, but also veterinarian products and knock-down products such as smoke used for beekeeping purposes. When focussing on studies dealing with ecotoxicity of xenobiotic compounds, two main objectives are targeted, the protection of the pollinating insects against the side-effects of the products, and the use of these insects as bio-indicators of pollution including radioelements. Publications reporting methods that aim to protect pollinating insects, or at least to predict the impact of products on bees, are still very numerous (more than 300 papers), but many of them examine the effects on wild pollinators and not on honey bees, several papers are published by the same authors or are review papers, and only the most recent papers (published after the 70's) actually address a risk assessment concern. Thus, about a hundred papers form the basis of the available information on the assessment of toxic compounds to bees. However, many fewer papers specifically deal with sublethal effects on the behaviour, although various approaches can be proposed.

Recently, in the case of Gaucho ${ }^{\circledR}$ treated sunflower seeds in France, which supposedly impairs honey bees behaviour, several methods were developed by different teams to evaluate sublethal effects of this insecticide on honey bees. Behaviours such as olfactory learning responses, recruiting dances, foraging behaviour etc., as well as colony development were studied (Pham-Delègue and Cluzeau, unpublished data; Kirchner, 1999; Colin et al., 2001; Decourtye et al., 2000; Guez et al., 2001; Lambin et al., 2001; Schmuck et al., 2001). Depending on the methods, different Lowest Observed Effect Concentrations were found, which questioned the value of these bioassays in terms of their representation of effects found under natural conditions. Sublethal effects were also reported for other pesticides, such as delayed mortality or disappearance after low dose treatment with cypermethrin (Bendahou et al., 1999), decreased egg laying due to sublethal doses of dimethoate (Lensing, 1986), or disruption of homing flights after exposure to sublethal doses of deltamethrin (Vandame et al., 1995).

In the present paper, we do not intend to give an exhaustive presentation of all the published studies, but only to present some studies that are of special interest for the estimation of behavioural effects of pesticides. In the honey bee, foraging is governed by individual learning and orientation abilities, and by social communication. We detail experimental procedures to assess the effects of low doses of pesticides on these specific behavioural processes. 


\subsection{Monitoring honey bees activity at the hive entrance}

When no visible mortality is detected in close proximity to the hive, it may be appropriate to quantify bee losses as a potential effect of insecticide treatment. Quantifying bee loss is also useful as a regular beekeeping practice to follow the hive activity. Several attempts were made to design automatic counters of outgoing and incoming honey bees. The first prototypes were based on the recording of electrical impulses (Lundie, 1925; Fabergé, 1943) or on the use of photoelectric signals (Brittain, 1933). Another system was designed by Chauvin (1952), based on a mechanical set up that distinguished between outgoing and incoming flights, which was easily adapted to Dadant hives. Based on Brittain's system, several works have progressively improved the functioning of the apparatus (Kerfoot, 1966; Spangler, 1969; Burril and Dietz, 1973; Erickson et al., 1975). More recently, modern systems introduced electronic counters, the use of infra-red light sensors, two sensor couples to discriminate the direction of the bee movement, and computer data analyses (Marletto and Piton, 1983; Rickly et al., 1989; Liu et al., 1990; Struye et al., 1994). These devices were robust and adapted to outdoor conditions. Therefore they were adequate to carry out semi-field or field trials to follow daily activity of the colonies and detect bee losses due to predators, pathogens, or poisoning. The most sophisticated system currently commercialised (BeeScan, Lowland Electronics, Belgium) comprises 32 bidirectional chanals with stairs to avoid a continuous bee flow, high resolution between two successive recordings, and good compatibility with standard statistical software. This device is still the only automatic counter available, and gives valuable data on the activity rhythm during the day although bad interpretation of the data may lead to incorrect conclusion as mentioned by the company which designed the counter (Struye, 2001). Shifts of this parameter may indicate avoidance behaviour when a contaminated source is presented, as shown when a high concentration (50 ppb) of imidacloprid was delivered to bees within cages (Decourtye et al., 2000). The potential use of this device for large-scale field experiments is still under evaluation.

\subsection{Orientation behaviour and dances}

When bee losses are observed, and insecticide intoxication is suspected, there may be alteration of the flight pattern between a contaminated food source and the hive. It can be hypothesized that the homing flight of the exposed forager or of the information given by the dances of the returning forager may be impaired.

The first hypothesis was tested by Vandame et al. (1995) who recorded the time needed to return to the hive when bees were exposed to deltamethrin in a tunnel. They found that treated bees flew towards the sun light, and took significantly more time to fly back to the hive. This disorientation was attributed to an effect on the storage or retrieval of spatial information. The parameters compared between treated and control bees were the angle between the hive and the feeder where bees were released ( $8 \mathrm{~m}$ from the hive) after treatment, and the homing flight duration. Such parameters appeared to be sensitive enough to reveal the effect of an insecticide. Similar experiments using other chemicals are needed to confirm the effect of various insecticides on the homing flight.

In addition, since the work of von Frisch (1967 for a review), it is recognized that dances produced by a returning forager code information about the distance and the direction of the food source. This coding ability was affected by prior exposure to sublethal doses of parathion, leading to changes in the angles of the dancing poisoned bees, or in the rhythm of the wagging dance (Schricker and Stephen, 1970; Schricker, 1974). The same approach was used by Kirchner (1999). He reported a reduction in the foraging activity on a food source contaminated with imidacloprid (20-100 ppb) due to the induction of trembling dances that prevent other bees from foraging. The information coded in the dances about distance and direction also was less precise. Such a method based on the recording of dance parameters (Kirchner and Lindauer, 1994) appears to be a valuable and sensitive tool to collect objective data on behavioural effects of an exposure to pesticides. However, these observations are time consuming and require much expertise by the observer, because they are based on the 
analysis of dance parameters from video recordings of tagged individuals.

\subsection{The proboscis extension response}

When landing on a flower, each forager is subjected to a conditioning process where floral cues (smell, colour, shape) are memorised after being associated with a food reward (nectar and pollen; Menzel and Müller, 1996). Under laboratory conditions, olfactory learning can be studied using a bioassay based on the conditioning of the proboscis extension reflex (PER) applied to restrained individuals (Takeda, 1961). Moreover, it has been shown that PER data in terms of time course of memory and olfactory discrimination abilities, are well correlated to olfactory responses of freeflying bees under cage or field conditions (Mauelshagen and Greggers, 1993; PhamDelègue et al., 1993; Laloi et al., 2000). This suggests that effects found in PER responses obtained under laboratory conditions may reflect effects that would occur under more realistic situations. In the case of insecticide poisoning, it is of interest to verify whether this correlation exists. The availability of a predictive laboratory assay to evaluate the impairment of foraging behaviour would be valuable to complement field or semi-field assays, which are often characterised by fluctuating conditions leading to difficulties in data interpretation. Several authors have tentatively used the PER bioassay to assess behavioural effects of pesticides.

The bioassay has been detailed by Bitterman et al. (1983) and Sandoz et al. (1995). It consists first in a conditioning phase where the conditioned stimulus CS (i.e. a floral odour) is presented simultaneously to the unconditioned stimulus US (sugar solution contacting the antennae, tarsae or mouthparts) and to the uptake of a sugar reward R. Second, an extinction phase is applied, where the CS alone is delivered. The honey bees can be exposed to the toxicant at various stages of the procedure:

(1) prior to the bioassay, which may be analogous to the case of bees feeding on contaminated food stored in the hive, before becoming foragers;
(2) during the conditioning phase, the product being administered in the reward, analogous to the exposure of foragers visiting a treated flower;

(3) between the conditioning and the extinction phases, to evaluate the effect of the product on the time course of memory.

Thus, a 24 h-exposure to a range of pyrethroids prior to the PER assay led to differential decreases in the acquisition of the conditioned response, allowing for a classification of the products (Taylor et al., 1987). Longer term exposure (11-12 days) to endosulfan or imidacloprid prior to conditioning induced a significant reduction in olfactory learning performances, whereas the same compounds added at the same concentration to the sucrose reward had no effect (Decourtye, 1998). But contamination in the reward solution with different products (endosulfan, Baytroid ${ }^{\circledR}$, Decis $^{\circledR}$, Sevin ${ }^{\circledR}$ ) may affect the learning process as shown by Abramson et al. (1999). Acquisition and extinction phases were differentially affected depending on the product. Complementarily, the products can be added to the CS to establish a possible repellent effect, impairing olfactory learning. Among the products used by Abramson et al. (1999), none had such a repellent effect. Finally, postconditioning exposure to permethrin did not disrupt further conditioned responses observed during the testing phase (Mamood and Waller, 1990).

Parallel to classical conditioning procedures, additional information can be obtained from more complex learning procedures such as a discriminative conditioning where one $\mathrm{CS}+$ is associated to a positive reward while an alternative $\mathrm{CS}$ - receives no reinforcement. This procedure facilitates the elicitation of conditioned responses to the CS+. Stone et al. (1997) indicated that this protocol produced responses more robust than those obtained in a standard PER procedure. Thus a $24 \mathrm{~h}$ pre-exposure to dicofol affected the learning abilities during the classical conditioning, but not during the discriminative procedure.

However, few studies have used the PER procedure to evaluate sublethal effects of pesticides on bees despite the fact that this approach appears promising. Indeed, conditioned 
learning is part of honey bees' natural behavioural repertoire, and it reflects food-location behaviour of free-flying foragers. PER conditioning allows controlled insecticide exposure and standardised recordings of behavioural responses. It also provides information on the mechanisms of memory impairment by toxicants. However, further work is needed to establish the variability of this response, since it has been shown that factors such as age, genetic origin, rearing conditions, and season, may affect the level of conditioned responses (Decourtye and Pham-Delègue, 2002). Furthermore, the general correlation between effects found under laboratory and more natural conditions remains questionable because of the discrepancy in the risk of exposure to a toxic. Pyrethroids provide a good example of the difficulty in interpreting laboratory data. In the field, these products are known to repel foragers, therefore exposure is much reduced in comparison to laboratory conditions. Although field or semi-field conditions are the most relevant to establish realistic risks, the PER assay could give additional specific information on the mechanisms involved.

\section{CONCLUSION}

The existing regulatory procedures for risk assessment, based on laboratory, semi-field and field assays, already provide a wide range of information on the potential effects of pesticides on honey bees. However, most assays are based on the recording of mortality, and little information is provided on sublethal effects, except in brood tests. Among sublethal effects, those affecting honey bee behaviour are of utmost importance, since behavioural impairment may have a strong consequence on pollination efficiency. To be reliable, a behavioural assay should fulfil several conditions: it should be reproducible, sensitive enough to low doses of toxic, easily carried out to facilitate the collection of objective and quantified data, and reflective of realistic situations. The behavioural assays mentioned above, could be developed for toxic evaluation purposes. However, for new testing methods, careful evaluation and validation of the tests are needed before a test can become eligible as a routine evaluation procedure.

One critical issue for such validation is the interpretation of the behavioural effects, since it is often not obvious how to relate such effects to a single factor like insecticide exposure. For example, the effect of an insecticide can be increased by the addition of a fungicide (Colin and Belzunces, 1992), or by various factors such as pollen feeding (Wahl and Ulm, 1983), season (Decourtye and Pham-Delègue, 2002) or genetic origin (Suchail et al., 2000). Another point to emphasize is the need to determine the actual exposure to the product, which is crucial to establish the link between the toxicity of a given product and the risk under field conditions. It requires the quantification of the amounts of residues in different locations (nectar, pollen, flower, hive), and with time. Such quantification requires the availability of reliable and highly sensitive chemical analyses (Bonmatin et al., 2000). Finally, whenever a behavioural effect is found under laboratory conditions, and reflects an impact of a toxic under natural conditions, the threshold of acceptable impairment has to be established at the honey bee population level. This acceptability threshold may depend on various considerations such as the impact on biodiversity, or the economic loss for beekeepers, or plant producers, or even the social concern about the environmental impact of pesticides. The behavioural methods presented herein are potential decision-making tools, and at least they could help in the understanding of mechanisms underlying insecticide toxicity.

\section{ACKNOWLEDGEMENTS}

We thank Anne-Marie Duprat and Jean-Noël Tasei for their help in gathering literature relevant to this review.

Résumé - Méthodes comportementales pour estimer les effets des pesticides sur les abeilles domestiques. Les abeilles domestiques (Apis mellifera L.) sont les principaux insectes pollinisateurs et peuvent être exposées de façon répétée à des pesticides, lorsqu'elles butinent des cultures traitées, ou dans la ruche si les réserves alimentaires contiennent des résidus. L'évaluation des risques environnementaux posés par les pesticides inclut des tests écotoxicologiques 
sur les abeilles domestiques. Ces tests ont pour but l'évaluation du risque, qui résulte de la combinaison de la toxicité du produit et de l'exposition réelle des abeilles à ce dernier. Pour ce faire, les tests suivent un schéma séquentiel fondé sur des évaluations au laboratoire, en conditions semi-naturelles ou naturelles, prenant en compte principalement la mortalité. Or, dans certains cas la toxicité d'un produit peut se traduire par des effets sublétaux. L'objectif de ce texte est de présenter des approches qui permettent de quantifier de tels effets sublétaux, notamment sur le comportement, composante clé de l'efficacité pollinisatrice et de la production de miel. Nous avons choisi de présenter des méthodes d'études comportementales objectives et quantifiées. Une première méthode s'appuie sur l'enregistrement de la fréquence des entrées et sorties de la ruche, qui indique l'activité de la colonie et peut être automatisée au moyen de compteurs d'abeille. Ces compteurs sont en cours de perfectionnement, mais des modèles sont déjà commercialisés. Ils permettent d'estimer des pertes d'abeilles domestiques liées à un traitement insecticide, grâce au bilan des entrées et sorties. Toutefois, leur utilisation potentielle à grande échelle est encore en cours de validation. D'autres méthodes sont basées sur l'observation du comportement d'orientation vers la ruche et de la communication sociale par les danses. Des perturbations de ces comportements à la suite d'exposition à des insecticides ont été observées, et peuvent être à l'origine de perte d'abeilles. Cependant l'analyse de ces comportements demeure assez longue et délicate. Enfin, l'extension conditionnée du proboscis, réponse utilisée par divers auteurs pour l'étude de la mémoire olfactive, présente des qualités essentielles pour son application en test d'écotoxicologie (sensibilité, mise en œuvre aisée). Mais les facteurs de variabilité de ces réponses, ainsi que leur corrélation avec le comportement au champ, restent à préciser. En conclusion, des essais comportementaux tels que ceux mentionnés pourraient être des outils d'évaluation d'effets sublétaux de pesticides, pour comprendre les mécanismes de l'intoxication, sous réserve de leur validation comme tests de routine en écotoxicologie.

Apis mellifera / écotoxicologie / évaluation du risque / pesticide / comportement

\footnotetext{
Zusammenfassung - Erfassung des Verhaltens als Methode zur Bestimmung der Wirkungen von Pestiziden auf Honigbienen. Honigbienen (Apis mellifera L.) sind die wichtigsten Bestäuber unter den Insekten. Sie können Pestiziden mehrfach ausgesetzt sein: im Volk bei der Aufnahme von kon-
}

taminiertem Futter und außerhalb des Volkes beim Beflug von behandelten Kulturpflanzen. Die Abschätzung des von Pestiziden im Freiland für die Honigbienen ausgehenden Risikos beruht auf einem schrittweisen Untersuchungsprogramm, das die Bewertung von Laborversuchen, von Versuchen unter kontrollierten Freilandbedingungen und von Feldversuchen beinhaltet. Diese Methoden berücksichtigen den Einfluss von unterschiedlichen Pestizidkonzentrationen auf die Lebensdauer der Bienen. In speziellen Fällen jedoch werden standardisierte Methoden benötigt, die den sublethalen Effekt, z.B. Änderungen im Verhalten, bewerten können. Sammelverhalten ist eine Schlüsselaktivität, das durch individuelle Lernprozesse, Orientierungsverhalten und soziale Kommunikation gesteuert wird. Deshalb haben wir experimentelle Verfahrensweisen vorgestellt, die eine Quantifizierung der Wirkung von Pestiziden auf diese Verhaltensfähigkeiten ermöglichen. Eine erste Methode bestimmt das Verhältnis von Ein- und Ausflügen, die die Aktivität des Volkes bewertet und für die eventuell automatisierten Zählapparaturen durchgeführt werden kann. Diese Apparaturen werden noch weiter verbessert, aber es gibt bereits Modelle zu kaufen. Sie ermöglichen, den insektizidbedingten Verlust von Honigbienen anhand der Bilanz von Ein- und Ausflügen zu bestimmen. Insgesamt muss ihre mögliche Nutzung für Routineuntersuchungen noch bestimmt werden. Andere Methoden beruhen auf der Beobachtung des Heimfindevermögens von Bienen und der Analyse der Information des Tanzes von heimgekehrten Sammlerinnen. Störungen dieses Verhaltens als Folge von Kontakt mit Insektiziden wurden bereits beobachtet und können die Ursache für Bienenverluste sein. Der konditionierte Rüsselreflex mit entsprechend fixierten Bienen eignet sich als ökotoxikologischer Test. Er wurde bisher von verschiedenen Autoren zur Bewertung der individuellen olfaktorischen Lernleistung benutzt. Bevor diese Verhaltensversuche als Routine zur Bestimmung von sublethaler Toxizität genutzt werden, müssen jedoch die Faktoren der Variabilität der Reaktionen und ihre Korrelation mit den Feldbedingungen präzisiert werden. Zusammenfassend lässt sich sagen, dass sowohl die zugelassenen Tests als auch die hier angeführten Versuche eingesetzt werden könnten, um den Mechanismus der Vergiftung zu verstehen. Weiter könnten sie unter dem Vorbehalt ihrer Anerkennung als Routineuntersuchungen in der Ökotoxikologie zur Abschätzung von sublethalen Wirkungen der Pestizide eingesetzt werden.

\section{Honigbienen / Ökotoxikologie / Risikoabschät- zung / Pestizide / Verhalten}




\section{REFERENCES}

Abramson C.I., Aquino I.S., Ramalho F.S., Price J.M. (1999) The effect of insecticides on learning in the Africanized honey bee (Apis mellifera L.), Arch. Environ. Contam. Toxicol. 37, 529-535.

Bendahou N., Fléché C., Bounias M. (1999) Biological and biochemical effects of chronic exposure to very low levels of dietary cypermethrin (Cymbush) on honeybee colonies (Hymenoptera: Apidae), Ecotoxicol. Environ. Saf. 44, 147-153.

Bitterman M.E., Menzel R., Fietz A., Schäfer S. (1983) Classical conditioning proboscis extension in honeybees (Apis mellifera), J. Comp. Psychol. 97, 107-119.

Bonmatin J.M., Moineau I., Colin M.E., Fléché C., Bengsch E.R. (2000) L'insecticide imidaclopride: biodisponibilité dans les sols et les plantes, toxicité et risque pour les abeilles, Abeilles et Fleurs 609, $360-361$.

Brittain W.H. (1933) Apple pollination studies in the Annapolis Valley, NS, Canada, 1928-1932, Can. Dept. Agric. Bull. 162, 119-125.

Burril R.M., Dietz A. (1973) An automatic honey bee counting and recording device for possible systems analysis of a standard colony, Am. Bee J. 113, 216-218.

Calderone N.W., Page R.E. (1992) Effects of interactions among genotypically diverse nestmates on task specialization in the honey bee Apis mellifera (Hymenoptera: Apidae), Behav. Ecol. Sociobiol. 30, 219-226.

Chauvin R. (1952) Nouvelle technique d'enregistrement de l'activité de la ruche, Apiculteur 96, 9-14.

Colin M.E., Belzunces L.P. (1992) Evidence of synergy between prochloraz and deltamethrin: a convenient biological approach, Pestic. Sci. 36, 115-116.

Colin M.E., Le Conte Y., Vermandère J.P. (2001) Managing nuclei in insect-proof tunnel as an observation tool for foraging bees, in: Belzunces L.P., Pélissier C., Lewis G.B. (Eds.), Hazards of pesticides to bees, Paris, INRA, les Colloques no 98, pp. 23-26.

Decourtye A. (1998) Étude des effets sublétaux de l'imidaclopride et de l'endosulfan sur l'apprentissage olfactif chez l'abeille domestique Apis mellifera L., Mémoire de DEA, Neurobiologie des Processus de Communication et d'Intégration, Université Montpellier II, 18 p.

Decourtye A., Pham-Delègue M.-H. (2002) The proboscis extension response as a laboratory method to assess the sublethal effects of pesticides on the honey bee, in: Devillers J., Pham-Delègue M.-H. (Eds.), Honey Bees: The Environmental Impact of Chemicals, Taylor \& Francis, London, pp. 67-74.

Decourtye A., Le Métayer M., Renou M., Pham-Delègue M.-H. (2000) Effets de doses sublétales de pesticides sur le comportement de l'abeille domestique Apis mellifera L., in: Actes Colloq. Insectes Soc., Tours France, pp. 105-113.

EPPO (1993) Decision-making schemes for the environmental risk assessment of plant protection products-honey bees, OEPP/EPPO Bull. 23, 151-165.

Erickson E.H., Miller H.H., Sikkema D.J. (1975) A method for separating and monitoring honeybee flight activity at the hive entrance, J. Apic. Res. 14, 119-125.
Fabergé A.C. (1943) An apparatus for recording the bees leaving and entering a hive, J. Sci. Instrum. 20, 28.

Frisch K. von (1967) The Dance Language and Orientation of Bees, Harvard University Press, Cambridge, 566 p.

Guez D., Suchail S., Gauthier M., Maleszka R., Belzunces L. (2001) Contrasting effects of imidacloprid on habituation in 7- and 8-day-old honeybees (Apis mellifera), Neurobiol. Learn. Memory 76, 183-191.

Kerfoot W.B. (1966) A photoelectric activity recorder for studies of insect behavior, J. Kans. Entomol. Soc. 39, 629-633.

Kirchner W.H. (1999) Mad-bee-disease? Sublethal effects of imidacloprid ("Gaucho") on the behavior of honeybees, Apidologie 30, 422.

Kirchner W.H., Lindauer M. (1994) The causes of trembling dance of the honey bee, Apis mellifera, Behav. Ecol. Sociobiol. 29, 303-308.

Laloi D., Bailez O., Blight M., Roger B., Pham-Delègue M.H., Wadhams L.J. (2000) Recognition of complex odors by restrained and free-flying honeybees, Apis mellifera, J. Chem. Ecol. 26, 2307-2319.

Lambin M., Armengaud C., Raymond S., Gauthier M. (2001) Imidacloprid-induced facilitation of the proboscis extension reflex habituation in the honeybee, Arch. Insect Biochem. Physiol. 48, 129-134.

Lensing W. (1986) Veränderungen bei den Arbeiterinnen der Honigbiene nach Fütterung von Dimethoat in subletalen Dosen, Apidologie 17, 339-342.

Liu C., Leonard J.J., Feddes J.J. (1990) Automated monitoring of flight activity at a beehive entrance using infrared light sensors, J. Apic. Res. 29, 170-173.

Lundie A.E. (1925) The flight activities of the honey bee, US Dept. Agric. Bull. No. 1328.

Mamood A.N., Waller G.D. (1990) Recovery of learning responses by honeybees follows a sublethal exposure to permethrin, Physiol. Entomol. 15, 55-60.

Marletto F., Piton P. (1983) Conta-api elettronico per la verifica dell'attività degli alveari, Apic. Mod. 74, 137-141.

Mauelshagen J., Greggers U. (1993) Experimental access to associative learning in honeybees, Apidologie 24, 249-266.

Menzel R., Müller U. (1996) Learning and memory in honeybees: From behavior to neural substrates, Annu. Rev. Neurosci. 19, 379-404.

Pham-Delègue M.H., Trouiller J., Caillaud C., Roger B., Masson C. (1993) Effect of queen pheromone on worker bees of different ages: Behavioural and electrophysiological responses, Apidologie 24, 267-281.

Rickly M., Buhlmann G., Gerig L., Herren H., Schürch H.J., Zeier W., Imdorf A. (1989) Zur Anwendung eines elektronischen Bienenzählgerätes am Flugloch eines Bienenvolkes, Apidologie 20, 305-3015.

Sandoz J.C., Roger B., Pham-Delègue M.H. (1995) Olfactory learning and memory in the honeybee: Comparison of different classical conditioning procedures of the proboscis extension response, C. R. Acad. Sci. Paris, Sci. Vie 318, 749-755.

Schmuck R., Schöning R., Stork A., Schramel O. (2001) Risk posed to honeybees (Apis mellifera L., Hymenoptera) by an imidacloprid seed dressing of sunflowers, Pest Manage. Sci. 57, 225-238. 
Schricker B. (1974) Der Einfluss subletaler Dosen von Parathion (E 605) auf das Zeitgedächtnis der Honigbiene, Apidologie 5, 385-398.

Schricker B., Stephen W.P. (1970) The effects of sublethal doses of parathion on honeybee behaviour. I. Oral administration and the communication dance, J. Apic. Res. 9, 141-153.

Seeley T.D. (1982) Adaptive significance of the age polyethism schedule in honeybee colonies, Behav. Ecol. Sociobiol. 11, 287-293.

Spangler H.G. (1969) Photoelectrical counting of outgoing and incoming honey bees, J. Econ. Entomol. 62, 1183-1184.

Stone J.C., Abramson C.I., Price J.M. (1997) Task-dependent effects of dicofol (kelthane) on learning in the honey bee (Apis mellifera), Bull. Environ. Contam. Toxicol. 58, 177-183.

Struye M.H. (2001) Possibilities and limitations of monitoring the flight activity of honey bees by means of BeeSCAN bee counters in: Belzunces L.P., Pélissier C., Lewis G.B. (Eds.), Hazards of pesticides to bees, Paris, INRA, les Colloques no 98, pp. 269-275.

Struye M.H., Mortier H.J., Arnold G., Miniggio C., Borneck R. (1994) Microprocessor-controlled moni- toring of honeybee flight activity at the hive entrance, Apidologie 25, 384-395.

Suchail S., Guez D., Belzunces L.P. (2000) Characteristics of imidacloprid toxicity in two Apis mellifera subspecies, Environ. Toxicol. Chem. 19, 1901-1905.

Takeda K. (1961) Classical conditioned response in the honey bee, J. Insect Physiol. 6, 168-179.

Taylor K.S., Waller G.D., Crowder L.A. (1987) Impairment of classical conditioned response of the honey bee (Apis mellifera L.) by sublethal doses of synthetic pyrethroid insecticides, Apidologie 18, 243-252.

Vandame R., Meled M., Colin M.E., Belzunces L.P. (1995) Alteration of the homing flight in the bee Apis mellifera L. exposed to sublethal dose of deltamethrin, Environ. Toxicol. Chem. 14, 855-860.

Wahl O., Ulm K. (1983) Influence of pollen feeding and physiological condition on pesticide sensitivity of the honey bee Apis mellifera carnica, Oecologia 59, 106-128.

Williams I.H. (1994) The dependence of crop production within the European Union on pollination by honey bees, Agric. Zool. Rev. 6, 229-257. 